\title{
Weaknesses of Translation Result Using Google Translate
}

\author{
Stefani Dewi Rosaria ${ }^{1}$, Rati Riana ${ }^{2}$ \\ \{stefani@usm.ac.id ${ }^{1}$, ratiriana61@yahoo.co.id² \\ Universitas Semarang, Indonesia ${ }^{1,2}$
}

\begin{abstract}
Google Translate has been widely used worldwide in more than 90 languages, and it becomes the most popular translation tool since then. Many people rely on this tool because they want easy and fast way to translating their text. But, like many tools created by human beings it has its own flaws. This descriptive qualitative research aims to analyze the weaknesses of translating result using Google Translate. The result of this study showed that even though this translation tool may solve people's problem in translating text, the translation result still needs revision because the result of translated text using Google Translate was too wordy and incomprehensible. The tool applied literal translation and often ignore the context contain in the text. Translation activity is not only altering the source language to the receptor language beyond that the translation result should be acceptable, understandable, readable, and natural.
\end{abstract}

Keywords: Translation, Google Translate, Weakness

\section{Introduction}

Undoubtedly technology always develops rapidly over centuries, as a result it brings changes in human life. Beginning from an invention of steaming machine by James Watt in 1776 the world of work became easier and efficient. For example, when ship became the main transportation utilizing ocean wind to travel to other countries, and before the steaming machine was invented, it took years to reach destination because sometime the wind, utilized to move the windmill, did not blow. So, the steaming machine was very helpful shortening time and saving cost. After the invention of steaming machine, in the early of 20th century, mass production of car using conveyor belt began. Applying an electrical power, conveyor belt, and assembly line had decreased the production time and production cost drastically. One car could be made in 95 minutes. In the third industrial revolution the first computer existed and the use of robot in the production process began. This era was also called digital revolution. Now, the 4.0 revolution in which the internet is used in many sectors, computer is much smaller than before and it is connected to internet. We can call it internet of things. In this era artificial intelligent begins to use even though it is still limited for particular jobs. Information can be accessed anywhere anytime through smartphone [1].

The growth of technology and information affects many sectors. The internet has changed our way of life. Shopping, for example, can be done online and it is not necessary to do face to face. In just one click we can purchase goods then wait them two or three days to be delivered. We can do shopping while we were at work or at home, and it saves our time and energy. Internet is information media for tourists when they visit other countries. All of 
information relates to their destination can be found through it. Internet also learning media for students and for people who have desire to learn something. For students, it helps them to find references or e-book to support their study. For people who eager to learn foreign language, nowadays they can learn through application such as busuu if they want to make friends with foreign people as well as leaning their language. So, if we want to learn French, we should make friend with the French, and they will teach us their language, moreover we can also teach our language to them. When we travel around the world and need to understand word or direction in the airport, train station, and other places, we can get help from Google Translate. This application also equipped with sound so that we can try to pronounce the foreign words. It also very useful for students or people who want to translate a text.

Google Translate, although it is widely used to translate text and very helpful, we cannot rely on this tool completely. Maulidiyah [2] states that Google Translate helps students with their learning, writing, reading, vocabulary, and translation, but they admitted that it cannot translate all words correctly. Furthermore, Chen at al. [3] also states that Google Translate can be used to translate the simple sentence, but the incorrect translation occurred when the original English sentences required higher level of comprehension. Based on those previous studies, this research attempts to describe the weaknesses of translated text using Google Translate.

Translation is an intellectual process, it involves deep thinking, comprehending, and understanding the text and knowledge both in its source language to the receptor language. In simple word, translation means transforming the source language to the receptor language. Unfortunately, if the process is merely about transforming the text into other languages, then it may ignore the essence of the translation itself. Translating a text means conveying information to others, then it should be communicative so that the readers get good understanding about the content of the information. If it is hard to understand then there must be something inappropriate in the translation result. The concept of translating a text is reproduce the meaning in the source language into the receptor language. It also should pay attention to the communicative aspects because the translation result should convey the message or the meaning of the source language to the receptor language correctly. The figure below illustrates how the process works according to Larson [4]:

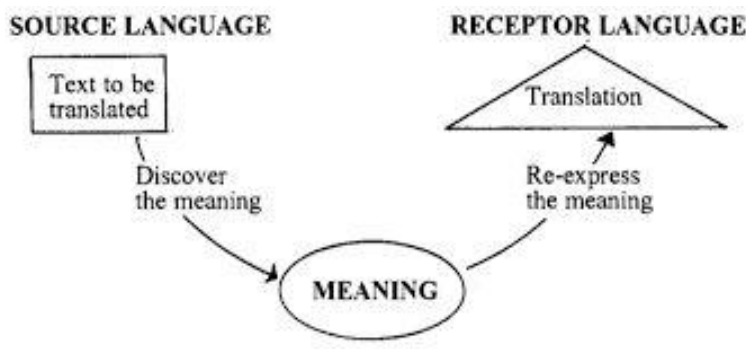

Fig 1. Process of Translation.

This research uses the underlying theory from Larson about literal and idiomatic translation. According to Larson [4] literal translation means a "word for word" translation which follows closely the form of the source language. After identifying the translation result using Google Translate, the researchers conclude that most of the result may apply the literal translation. On the other hand, idiomatic translation means that the translation result should be 
express the same meaning as the source of language but in a natural form of the receptor language [4].

Furthermore, the idiomatic translation is said to the translator's goal. Larson [4] states that when a translator makes a translation it means that he or she transfers meaning of the source text. So, it is necessary to consider that meaning must be maintain constantly or, in other words, when the change of the form occurs, the meaning must be maintaining, it is characteristic of language that the same meaning component will occur in several surface structure of lexical items (forms) [5].

\section{Methodology}

This research was descriptive qualitative research design, it means that the researchers described or gave description of the matter being analyzed. The descriptive qualitative does not deal with variables, treatment, or manipulation. Moreover, it rather explains the phenomena or condition and gives details to characteristic or qualities [6]. The objects of this research were two reading passages written in English, and both of them related to English for Law material since the researchers are lecturers who teach in Law Faculty. The first passage discussed the Law and Justice, while the second one talked about Consumer Rights. The data were taken from English for Law material taught in Universitas Semarang for students of Law Faculty. The reason why those reading passages were chosen because reading material for Law students often hard to understand because of some special terms used in the passage, for example, the passage entitled Consumer Rights contained special terms such as wear and tear, fit for purpose, proof of purchase. The researchers were wondering how the translation result using translation tool called Google Translate explains or transform such terms. To analyze the data, content analysis was used. The objective in qualitative content analysis is to systematically transform a large amount of text into a highly organized and concise summary of key result [7]. Moreover, content analysis is used to analyze text or document, in this case the translation text specifically the text from English language which transferred to Bahasa Indonesia. In short, in content analysis the systematic procedure should be applied to analyze the data to obtain the main idea of the text. The analysis procedures used in this research were as follow (see Figure 2).

There were four stages in analyzing the data, they are analyzing, interpreting, synthesizing, and documenting. First of all, analyzing, in this stage the researchers were reading the text as well as understanding the meaning and the context. The specific vocabulary and certain term were noted. Next, the researchers attempted to do free or raw interpretation before transferring into the receptor language. After that, synthesizing was done by integrating the sentences, phrases, certain terms or words into acceptable sentence structure by regarding the context. The last stage was documentation. In this stage the researchers began to develop final and correct translation result, and when everything was covered up, the researchers reread the translation result in order to check any possible mistake. 


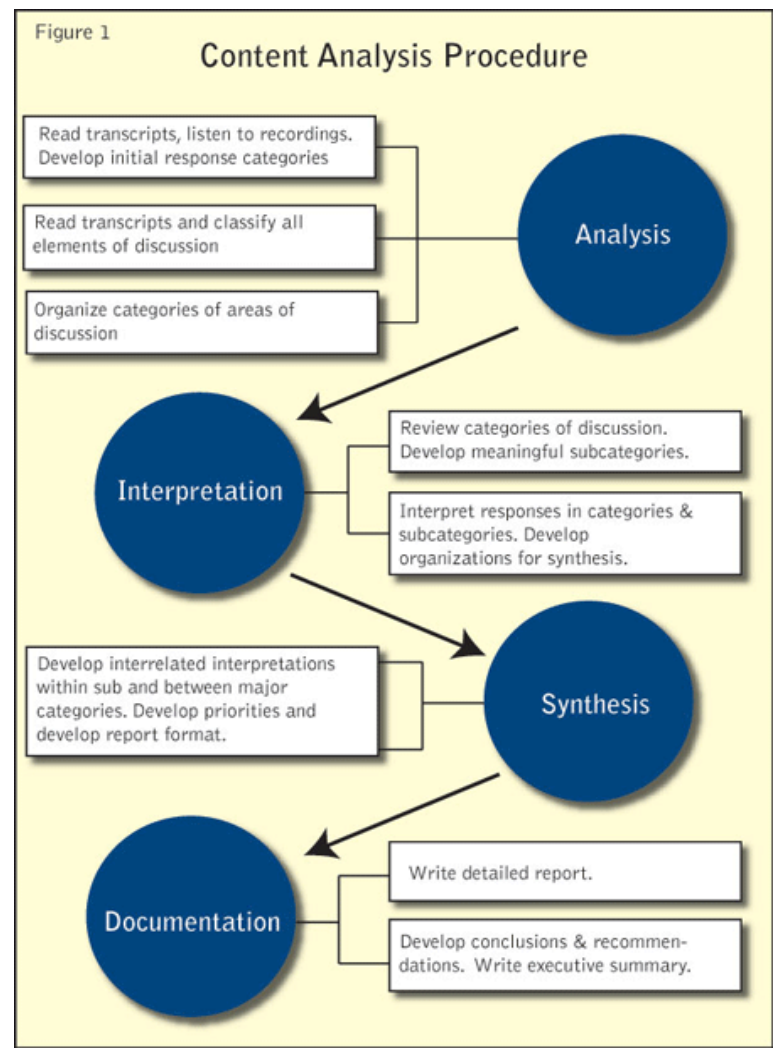

Fig. 2. Content Analysis Procedure [8].

\section{Findings and Discussion}

\subsection{Findings}

There were two reading passages which were being analyzed. Both of them related to English for Law material and were taught to students of Law Faculty at Universitas Semarang. The first passage entitled Law and Justice discussed how law and justice were defining, especially in society. Then, the second passage entitled Consumer Rights talked about kinds of rights had by consumers when they made transaction or shopping through an online shop. It was found that the first passage was more complicated and quite difficult to be translated than the second one.

The finding showed most of the data in TL1 was translated literally using Google Translate. The translation tool could not consider the context containing in the text. As a result, many words and terms in the source language could not be translated appropriately and properly. This could be seen in the data $02,03,09,10,11,12,13,14$. The other problems found in the translation result using Google Translate were verbose sentences which created 
ineffective sentences such as in data $01,04,15$. There were two acceptable-translation results by Google Translate as seen in data 07 and 08 .

\subsection{Discussion}

The discussions of the findings were described as follow:

Table 1. Data 01

\begin{tabular}{|c|c|c|}
\hline Source Language & $\begin{array}{c}\text { Target Language } 1 \text { (TL1) } \\
\text { GT01 }\end{array}$ & $\begin{array}{c}\text { Target Language } 2 \text { (TL2) } \\
\text { NG01 }\end{array}$ \\
\hline $\begin{array}{l}\text { Human beings have always } \\
\text { lived together under rules of } \\
\text { one kind or another. These } \\
\text { rules are likely to be influenced } \\
\text { by nature or the natural } \\
\text { environment of the society in } \\
\text { which people live, and the } \\
\text { simple natural instinct } \\
\text { everyone has for survival. } \\
\text { They may be influenced by } \\
\text { religious or secular beliefs, and } \\
\text { they will cater for the ideas of } \\
\text { right and wrong that have been } \\
\text { developed over time to suit the } \\
\text { society we live in. All the rules } \\
\text { which are designed to improve } \\
\text { our lives and protect us from } \\
\text { harm are called laws. }\end{array}$ & $\begin{array}{l}\text { Manusia selalu hidup bersama di } \\
\text { bawah aturan dari satu jenis } \\
\text { atau lainnya. Aturan-aturan ini } \\
\text { cenderung dipengaruhi oleh } \\
\text { alam atau lingkungan alami } \\
\text { masyarakat tempat orang } \\
\text { hidup, dan naluri alamiah } \\
\text { sederhana yang dimiliki setiap } \\
\text { orang untuk bertahan hidup. } \\
\text { Mereka mungkin dipengaruhi } \\
\text { oleh kepercayaan agama atau } \\
\text { sekuler, dan mereka akan } \\
\text { memenuhi gagasan benar dan } \\
\text { salah yang telah dikembangkan } \\
\text { dari waktu ke waktu sesuai } \\
\text { dengan masyarakat tempat kita } \\
\text { tinggal. Semua aturan yang } \\
\text { dirancang untuk meningkatkan } \\
\text { kehidupan kita dan melindungi } \\
\text { kita dari bahaya disebut hukum. }\end{array}$ & $\begin{array}{l}\text { Manusia selalu hidup bersama } \\
\text { sesuai dengan aturan. Aturan- } \\
\text { aturan ini dipengaruhi oleh } \\
\text { alam atau lingkungan alami } \\
\text { masyarakat dan naluri } \\
\text { alamiah sederhana yang } \\
\text { dimiliki setiap orang untuk } \\
\text { bertahan hidup. Mereka } \\
\text { mungkin dipengaruhi oleh } \\
\text { kepercayaan agama atau } \\
\text { sekuler dan mereka akan } \\
\text { memenuhi gagasan benar dan } \\
\text { salah yang telah } \\
\text { dikembangkan dari waktu ke } \\
\text { waktu sesuai dengan } \\
\text { masyarakat tempat kita } \\
\text { tinggal. Semuar aturan } \\
\text { dirancang untuk } \\
\text { meningkatkan kehidupan dan } \\
\text { melindungi kita dari masalah } \\
\text { disebut hukum. }\end{array}$ \\
\hline
\end{tabular}

The translation result using Google Translate (GT01) was too long and complicated, as a result it is hard to understand. There were words which actually did not need to be used, such as tempat orang hidup because it basically has the same meaning with alam dan lingkungan alami manusia which explained about where the human live. Punctuation also played important role. The use of unnecessary punctuation made the meaning unclear. On the other hand, the translation result in NG01 was more effective, shorter, and more understandable.

Table 2. Data 02

\begin{tabular}{llll}
\hline Source Language & \multicolumn{2}{c}{ Target Language 1 (TL1) } & Target Language 2 (TL2) \\
GT02 & NG02 \\
\hline $\begin{array}{l}\text { There are rules that are basic, } \\
\text { commonsense rules of aturan yang mendasar, }\end{array}$ & Ada aturan yang mendasar \\
everyday life (for example, & yaitu aturan akal sehat dari & dan masuk akal dalam \\
we must not kill or rob), that & (misalnya, kita tidak boleh & (misalnya, kita tidak boleh \\
forbid things which everyone & membunuh atau merampok), & membunuh atau merampok). \\
thinks are plainly or morally & aturan yang melarang hal-hal & Aturan yang melarang hal-hal \\
wrong. There are rules which & yang oleh semua orang & yang dianggap salah atau \\
govern important things and & dianggap jelas salah atau secara & secara moral salah. Ada \\
\hline
\end{tabular}


relations in our particular community, about which we have learned from experience (for example, the driver and the passenger in a car must wear seat belts, which provide protection from injury). There are rules which have gradually developed over a period of many years, and have grown out of custom which has settled as the accepted way of behavior. moral salah. Ada aturan yang mengatur hal-hal penting dan hubungan dalam komunitas khusus kami, yang telah kami pelajari dari pengalaman (misalnya, pengemudi dan penumpang dalam mobil harus mengenakan sabuk pengaman, yang memberikan perlindungan dari cedera). Ada peraturan yang secara bertahap berkembang selama bertahuntahun, dan telah tumbuh dari kebiasaan yang telah ditetapkan sebagai cara perilaku yang diterima. aturan yang mengatur hal-hal penting dan hubungan dalam komunitas tertentu (misalnya, pengemudi dan penumpang dalam mobil harus mengenakan sabuk pengaman untuk memberikan perlindungan dari cedera). Ada peraturan yang secara bertahap berkembang selama bertahun-tahun dan tumbuh dari kebiasaan yang diterima masyarakat sebagai cara berperilaku.

The next translation result in GT02 results confusing terms such as aturan akal sehat which has different meaning with what actually was meant by the source language, so it was corrected to aturan yang masuk akal. The word particular was translated khusus (special) which directed to different meaning. It is true that the word particular has the same meaning as special but when it is translated to the target language the meaning was different.

Table 3. Data 03

\begin{tabular}{|c|c|c|}
\hline Source Language & $\begin{array}{c}\text { Target Language } 1 \text { (TL1) } \\
\text { GT03 }\end{array}$ & $\begin{array}{c}\text { Target Language } 2 \text { (TL2) } \\
\text { GT03 }\end{array}$ \\
\hline $\begin{array}{l}\text { Justice, in the other hand, is a } \\
\text { difficult concept, chiefly } \\
\text { because everybody has a } \\
\text { different subjective idea what it } \\
\text { is, and it depends on these } \\
\text { moral principles known as } \\
\text { ethics, which differ from } \\
\text { person to person. }\end{array}$ & $\begin{array}{l}\text { Keadilan, di sisi lain, adalah } \\
\text { konsep yang sulit, terutama } \\
\text { karena setiap orang memiliki } \\
\text { gagasan subyektif yang berbeda } \\
\text { apa itu, dan itu tergantung pada } \\
\text { prinsip-prinsip moral yang } \\
\text { dikenal sebagai etika, yang } \\
\text { berbeda dari orang ke orang. }\end{array}$ & $\begin{array}{l}\text { Keadilan, di sisi lain, } \\
\text { merupakan konsep yang sulit, } \\
\text { terutama karena setiap orang } \\
\text { memiliki gagasan subjektif } \\
\text { tentang keadilan dan gagasan } \\
\text { tersebut tergantung pada } \\
\text { prinsip-prinsip moral yang } \\
\text { dikenal sebagai etika yang } \\
\text { berbeda bagi setiap orang. }\end{array}$ \\
\hline
\end{tabular}

In table 3 above, the result of GT03 especially the phrase what it is was translated literally, so it created confusion because that phrase did not explain what it referred to. It should be refered to keadilan, then it was clearer to understand the translation result in NG03. The phrase orang ke orang should be meant setiap orang because it was more effective.

Table 4. Data 04

\begin{tabular}{|c|c|c|}
\hline Source Language & $\begin{array}{c}\text { Target Language } 1 \text { (TL1) } \\
\text { GT04 }\end{array}$ & $\begin{array}{c}\text { Target Language } 2 \text { (TL2) } \\
\text { NG04 }\end{array}$ \\
\hline $\begin{array}{l}\text { One simple idea of justice is } \\
\text { the upholding of rights, and the } \\
\text { punishment of wrongs, by the } \\
\text { law. That is what we mean by } \\
\text { fairness, and dealing with legal } \\
\text { issues and problems according } \\
\text { to the rules that are exactly the }\end{array}$ & $\begin{array}{l}\text { Satu gagasan } r \text { sederhana } \\
\text { tentang keadilan adalah } \\
\text { penegakan hak, dan hukuman } \\
\text { atas kesalahan, oleh hukum. } \\
\text { Itulah yang kami maksud } \\
\text { dengan keadilan, dan } \\
\text { berurusan dengan masalah }\end{array}$ & $\begin{array}{l}\text { Jagasan sederhana tentang } \\
\text { readilan adalah penegakan hak } \\
\text { lan penjatuhan hukuman atas } \\
\text { resalahan yang berlaku sama } \\
\text { intuk setiap orang. Gagasan } \\
\text { yang kuat tentang keadilan } \\
\text { tdalah adil, terbuka, dan tidak }\end{array}$ \\
\hline
\end{tabular}


same for everyone. We have a strong idea of the rules of natural justice: the basic requirements of a fair, open hearing, impartial court (whether judge or jury), giving each side an equal chance to state its case and to call evidence in support of it, and listening to the arguments of each side before coming to a reasoned decision. This is what we call the fair manner of doing justice according to law.

\begin{tabular}{|c|c|}
\hline $\begin{array}{l}\text { dengan aturan yang persis } \\
\text { sama untuk semua orang. } \\
\text { Kami memiliki gagasan yang } \\
\text { kuat tentang aturan keadilan } \\
\text { alami: persyaratan dasar } \\
\text { pengadilan yang adil, terbuka, } \\
\text { dan tidak memihak (apakah } \\
\text { hakim atau juri), memberikan } \\
\text { masing-masing pihak } \\
\text { kesempatan yang sama untuk } \\
\text { menyatakan kasusnya dan } \\
\text { untuk memanggil bukti yang } \\
\text { mendukungnya, } \\
\text { mendengarkan dan } \\
\text { masing-masing pihak sebelum } \\
\text { membuat keputusan yang } \\
\text { masuk akal. Inilah yang kami } \\
\text { sebut cara adil untuk } \\
\text { melakukan keadilan menurut }\end{array}$ & $\begin{array}{l}\text { nemihak (baik hakim maupun } \\
\text { uri). Mereka memberikan } \\
\text { sesempatan yang sama kepada } \\
\text { iap-tiap pihak untuk } \\
\text { nenjelaskan kasusnya dan } \\
\text { nemberikan bukti yang } \\
\text { nendukungnya, } \\
\text { nendengarkan serta } \\
\text { nasing-masing pihak sebelum } \\
\text { nembuat keputusan yang } \\
\text { nasuk akal. Ini merupakan } \\
\text { sara untuk menegakkan } \\
\text { seadilan menurut hukum. }\end{array}$ \\
\hline
\end{tabular}

dan masalah hukum sesuai Kami memiliki gagasan yang kuat tentang aturan keadilan persyaratan dasa hakim atau juri), memberikan masing-masing pihak kesempatan yang sama untuk menyatakan kasusnya dan untuk memanggil bukti yang mendukungnya, dan mendengarkan argumen masuk akal. Inilah yang kami melakukan hukum.

Data 04 above showed that the translation result using google translate did not explain straight forward to the point. It resulted long, absurd and ineffective translation result. The expression call the evidence was not translated properly, it became memanggil bukti. Such expression was not used in the receptor language. Moreover, it was hard to understand the main idea because in target language (receptor language) it sounded unnatural. When it is translated without using the tool, the result was better to understand, the main point was very clear, and it was shorter because it used effective word.

Table 5. Data 05

\begin{tabular}{lllllr}
\hline \multicolumn{1}{c}{ Source Language } & \multicolumn{2}{c}{ Target Language 1 (TL1) } & \multicolumn{2}{c}{ Target Language 2 (TL2) } \\
NG05
\end{tabular}




\begin{tabular}{llll}
\hline fairly with those & pengadilan pertama-tama & memperbaikinya & adalah \\
responsibilities for breaking & memutuskan dengan prosedur & pengadilan memutuskan \\
the law and those who have & yang adil apa yang telah terjadi sesuatu secara adil dan \\
suffered because of it. & dan kemudian, jika hukum telah bertanggung jawab atas \\
& dilanggar, untuk menangani pelanggaran hukum. & \\
& secara adil tanggung jawab & \\
& untuk melanggar hukum dan & \\
mereka yang menderita & \\
karenanya. &
\end{tabular}

Data 05 was interesting since choosing the right diction in translation process was proved very significant. The source language used the word society and citizen in the same line, then it was translated to masyarakat dan warga in the receptor language which actually has the same meaning. When words having the same meaning were put together in the same line, it created unclear meaning so it should be the translator's job to make a make-sense meaning. He should consider the context to build an understandable text. The result was society was translated to pemerintah regarding the party which provides law or court is government or state. Then, a make-sense meaning emerged.

The word framework was not appropriate to be translated as kerangka kerja because it is out of the context. It should be translated as guideline (pedoman) since the context discussed about rule or law to govern the citizen. Considering the context plays important role to produce good translation, it cannot be left behind.

Table 6. Data 06

\begin{tabular}{|c|c|c|}
\hline Source Language & $\begin{array}{c}\text { Target Language } 1 \text { (TL1) } \\
\text { GT06 }\end{array}$ & $\begin{array}{c}\text { Target Language } 2 \text { (TL2) } \\
\text { NG06 }\end{array}$ \\
\hline $\begin{array}{l}\text { The law marks out the limits } \\
\text { of our power of individuals to } \\
\text { control their affairs. In our } \\
\text { modern society, ignorance of } \\
\text { law deprives people of their } \\
\text { legal rights. Therefore, } \\
\text { knowledge of law is the way } \\
\text { in which we can safeguard } \\
\text { ourselves, our families and } \\
\text { our possessions, by assuring } \\
\text { ourselves of the rights and } \\
\text { remedies which the legal } \\
\text { system provides. }\end{array}$ & $\begin{array}{l}\text { Hukum menandai batas-batas } \\
\text { kekuatan individu kita untuk } \\
\text { mengendalikan urusan mereka. } \\
\text { Dalam masyarakat modern kita, } \\
\text { ketidaktahuan hukum } \\
\text { merampas hak-hak hukum } \\
\text { orang. Karena itu, pengetahuan } \\
\text { hukum adalah cara di mana kita } \\
\text { dapat melindungi diri kita } \\
\text { sendiri, keluarga kita, dan } \\
\text { harta benda kita, dengan } \\
\text { meyakinkan diri kita sendiri } \\
\text { akan hak dan upaya hukum yang } \\
\text { disediakan oleh sistem hukum. }\end{array}$ & $\begin{array}{l}\text { Hukum membatasi hak setiap } \\
\text { individu untuk melakukan } \\
\text { urusan mereka. Dalam } \\
\text { masyarakat modern, } \\
\text { pengabaian hukum berarti } \\
\text { perampasan hak-hak } \\
\text { hukum orang lain. Oleh } \\
\text { karena itu, penguasaan } \\
\text { pengetahuan tentang hukum } \\
\text { merupakan cara kita } \\
\text { melindungi diri, keluarga, } \\
\text { dan harta benda dengan } \\
\text { meyakinkan diri akan hak dan } \\
\text { upaya hukum yang disediakan } \\
\text { oleh sistem hukum. }\end{array}$ \\
\hline
\end{tabular}

Data 06 the phrase the power of individuals tend to the individual rights, not the power of individual because the context told us about the people' rights. If the word power was not interpreted as sort of authority in this context. The ineffective expression because of repetition emerged in the phrase diri kita sendiri, keluarga kita, dan harta benda kita, to be effective the repetition must be omitted, and the meaning still remains the same. The word ignorance did not fit right with the word ketidaktahuan because it brought different meaning. ketidaktahuan akan hukum suggested that people must truly understand the law and order, in fact not all people study Law. Then the more appropriate word to interpret the phrase 
ignorance of law can deprive the people legal rights was pengabaian which means people who does not care the Law will interfere other's rights.

Table 7. Data 07

\begin{tabular}{|c|c|c|}
\hline Source Language & $\begin{array}{c}\text { Target Language } 1 \text { (TL1) } \\
\text { GT07 }\end{array}$ & $\begin{array}{c}\text { Target Language } 2 \text { (TL2) } \\
\text { NG07 }\end{array}$ \\
\hline $\begin{array}{l}\text { However, any system } \\
\text { operated by human beings, } \\
\text { with all our failings and } \\
\text { despite all the safeguards, is } \\
\text { fallible. To ensure that the } \\
\text { legal system works properly } \\
\text { and fairly, it is also important } \\
\text { to understand that our laws } \\
\text { and legal system are forever } \\
\text { in need of review and reform, } \\
\text { to adapt them to the changing } \\
\text { needs of society. }\end{array}$ & $\begin{array}{l}\text { Namun, sistem apa pun yang } \\
\text { dioperasikan oleh manusia, } \\
\text { dengan semua kegagalan kita } \\
\text { dan terlepas dari semua } \\
\text { perlindungan, bisa salah. Untuk } \\
\text { memastikan bahwa sistem } \\
\text { hukum berfungsi dengan baik } \\
\text { dan adil, penting juga untuk } \\
\text { memahami bahwa hukum dan } \\
\text { sistem hukum kita selamanya } \\
\text { perlu ditinjau dan direformasi, } \\
\text { untuk menyesuaikannya dengan } \\
\text { perubahan kebutuhan } \\
\text { masyarakat. }\end{array}$ & $\begin{array}{l}\text { Namun, sistem apa pun yang } \\
\text { dijalankan oleh manusia, } \\
\text { terlepas dari kegagalan dan } \\
\text { upaya perlindungannya, bisa } \\
\text { saja salah. Untuk memastikan } \\
\text { bahwa sistem hukum } \\
\text { berfungsi dengan baik dan } \\
\text { adil, harus dipahami bahwa } \\
\text { hukum dan sistem hukum kita } \\
\text { perlu ditinjau dan diperbaiki } \\
\text { selamanya agar sesuai dengan } \\
\text { perubahan masyarakat. }\end{array}$ \\
\hline
\end{tabular}

The result of translation in data 07 through google translate was acceptable. it means that the text can be understood easily by the reader. Even though the form of the sentences was different, GT07 was active and NG07 was passive, there was no discrepancy in meaning. The active voice focuses on the agents. In contrast, the passive voice focuses on the object that is acted upon.

Table 8. Data 08

\begin{tabular}{|c|c|c|}
\hline Source Language & $\begin{array}{c}\text { Target Language } 1 \text { (TL1) } \\
\text { GT08 }\end{array}$ & $\begin{array}{c}\text { Target Language } 2 \text { (TL2) } \\
\text { NG08 }\end{array}$ \\
\hline $\begin{array}{l}\begin{array}{l}\text { Providers of goods } \\
\text { services and } \\
\text { providers ancluding credit } \\
\text { companies) and }\end{array} \\
\text { responsibilities hire } \\
\text { liabilities towards the } \\
\text { customer which are aimed at } \\
\text { protecting the customer and } \\
\text { his/her rights. }\end{array}$ & $\begin{array}{l}\text { Penyedia barang dan jasa } \\
\text { (termasuk penyedia kredit dan } \\
\text { perusahaan sewaan) semuanya } \\
\text { memiliki tanggung jawab dan } \\
\text { kewajiban terhadap pelanggan } \\
\text { yang ditujukan untuk } \\
\text { melindungi pelanggan dan hak- } \\
\text { haknya. }\end{array}$ & $\begin{array}{l}\text { Penyedia barang dan jasa } \\
\text { (termasuk pemberi kredit dan } \\
\text { perusahaan jasa) memiliki } \\
\text { tanggung jawab dan } \\
\text { kewajiban terhadap } \\
\text { pelanggan dengan tujuan } \\
\text { untuk melindungi hak-hak } \\
\text { pelanggan. }\end{array}$ \\
\hline
\end{tabular}

The data in GT08 showed that the translation result was quite acceptable because the meaning was clear, but in NG08 when the phrase melindungi pelanggan dan hak-haknya was changed into melindungi hak-hak pelanggan the meaning was clearer and specifically emphasized that costumer's right was matter. While the phrase melindungi pelanggan dan hak-haknya was ambiguous because protecting the costumers must include protecting their rights as well, so it was more effective when the phrase was changed into melindungi hak-hak pelanggan. 
Table 9. Data 09

\begin{tabular}{lll}
\hline \multicolumn{1}{c}{ Source Language } & \multicolumn{1}{c}{ Target Language 1 (TL1) } & Target Language 2 (TL2) \\
NG09
\end{tabular}

Data 09 showed some special terms 'as described' and 'fit for purpose' and those terms were given explanation in the parentheses. Actually, the given explanation helped the translator to understand what the words were meant. A translator should find the equivalent term in the receptor language, but if there was no such similar term in the receptor language then a translator can interpret through the given explanation. The problem with the pronoun was seen in the word they which referred to goods. That was correct, but once it was translated to GT09 goods was translated to barang (singular noun), and they were translated to mereka. There was a gap in a matter of translating pronoun because Indonesian language does not divide or explain pronoun as English language does. As a result, in TL01 the word mereka to refer goods seemed inappropriate, so in NG09 to make it clearer the researchers used barang tersebut. Then the translation result became more understandable and effective.

Table 10. Data 10

\begin{tabular}{lllllc}
\hline \multicolumn{2}{c}{ Source Language } & \multicolumn{2}{c}{ Target Language 1 (TL1) } & \multicolumn{2}{c}{ Target Language 2 (TL2) } \\
GT09 & \multicolumn{2}{c}{ NG09 } \\
\hline All goods must carry a & $\begin{array}{l}\text { Semua barang harus membawa } \\
\text { guarantee or warranty in case } \\
\text { jaminan atau garansi jika }\end{array}$ & $\begin{array}{l}\text { Semua barang } \\
\text { miliki jaminan }\end{array}$ \\
they go wrong or do not meet & mereka salah atau tidak garansi agar jika terjadi \\
your expectations. & memenuhi harapan Anda. & $\begin{array}{l}\text { kesalahan atau tidak sesuai } \\
\text { dengan harapan Anda bisa }\end{array}$ \\
\hline
\end{tabular}

Words may have more than one meaning; moreover, it may have different meaning when falling into different context, for example the word carry above. In TL01 it was translated into membawa which is correct literally, but it did not fit right to the words which followed, jaminan atau garansi. In Indonesian language membawa is verb or predicate and it needs animate subject to bring something or to do that activity. So, in TL02 the proper word to explain the guarantee or warranty which must be had by all goods was the word memiliki (have). To make the word fit or suit with its meaning, a translator must think of the context and find the equivalent word to describe the meaning of particular word. 
Table 11. Data 11

\begin{tabular}{|c|c|c|}
\hline Source Language & $\begin{array}{c}\text { Target Language } 1 \text { (TL1) } \\
\text { GT10 }\end{array}$ & $\begin{array}{c}\text { Target Language } 2 \text { (TL2) } \\
\text { NG10 }\end{array}$ \\
\hline $\begin{array}{l}\text { If you need to return goods a } \\
\text { shop or other supplier, you } \\
\text { should do so within a } \\
\text { reasonable time: many shops } \\
\text { and suppliers specify their own } \\
\text { limit, usually } 28 \text { days, and can } \\
\text { refuse to do anything if there is } \\
\text { evidence of unreasonable wear } \\
\text { and tear (signs that the goods } \\
\text { have been used more than is } \\
\text { normal or for a purpose for } \\
\text { which they were not designed). }\end{array}$ & $\begin{array}{l}\text { Jika Anda perlu mengembalikan } \\
\text { barang ke toko atau pemasok } \\
\text { lain, Anda harus melakukannya } \\
\text { dalam waktu yang wajar: } \\
\text { banyak toko dan pemasok } \\
\text { menentukan batasnya sendiri, } \\
\text { biasanya } 28 \text { hari, dan dapat } \\
\text { menolak untuk melakukan apa } \\
\text { pun jika ada bukti keausan yang } \\
\text { tidak masuk akal (tanda-tanda } \\
\text { bahwa barang telah digunakan } \\
\text { lebih dari normal atau untuk } \\
\text { tujuan yang tidak dirancang). }\end{array}$ & $\begin{array}{l}\text { Jika Anda } \\
\text { mengembalikan barang ke } \\
\text { toko, Anda hin } \\
\text { melakukannya dalam batas } \\
\text { waktu yang telah } \\
\text { ditentukan. Banyak toko } \\
\text { menentukan batas waktunya } \\
\text { sendiri, biasanya } 28 \text { hari dan } \\
\text { dapat menolak untuk } \\
\text { melakukan apa pun jika ada } \\
\text { bukti kerusakan } \\
\text { pemakaian yang tidak } \\
\text { wajar (tanda-tanda bahwa } \\
\text { barang telah digunakan lebih } \\
\text { dari normal atau tidak sesuai } \\
\text { dengan } \\
\text { pakai/penggunaannya). }\end{array}$ \\
\hline
\end{tabular}

There were two terms, reasonable time and wear and tear, which attracted the researcher's attention. The text talked about the procedure to return goods customers had already purchased. In TL1 the reasonable time was translated to dalam waktu yang wajar, when we purchased something there is a procedure in certain length of time that we can return the goods, and we can see from the text 28 days was the limit. So, it was clear agreement between the consumer and the shop. As a result, it would be better if reasonable time was translated to dalam batas waktu yang telah ditentukan. The term dalam waktu yang wajar illustrated uncertain time whereas the limit has actually been specified, 28 days

Table 12. Data 12

\begin{tabular}{|c|c|c|}
\hline Source Language & $\begin{array}{c}\text { Target Language } 1 \text { (TL1) } \\
\text { GT12 }\end{array}$ & $\begin{array}{c}\text { Target Language } 2 \text { (TL2) } \\
\text { NG12 }\end{array}$ \\
\hline $\begin{array}{l}\text { If you take goods back to a } \\
\text { shop, they are entitled to ask } \\
\text { for proof of purchase, such as } \\
\text { a receipt, a credit card slip, etc, } \\
\text { that shows you actually bought } \\
\text { the goods from them. }\end{array}$ & $\begin{array}{l}\text { Jika Anda membawa barang } \\
\text { kembali ke toko, mereka berhak } \\
\text { meminta bukti pembelian, } \\
\text { seperti kwitansi, slip kartu } \\
\text { kredit, dll, yang menunjukkan } \\
\text { bahwa Anda benar-benar } \\
\text { membeli barang dari mereka. }\end{array}$ & $\begin{array}{l}\text { Jika Anda mengembalikan } \\
\text { barang ke toko, pihak toko } \\
\text { berhak meminta bukti } \\
\text { pembelian, seperti struk } \\
\text { belanja, slip kartu kredit } \\
\text { yang menunjukkan bahwa } \\
\text { Anda benar-benar membeli } \\
\text { barang dari mereka. }\end{array}$ \\
\hline
\end{tabular}

As we can see from the table, the phrase 'take goods back to a shop' was literally translated into membawa barang kembali ke toko. Unfortunately, the context of 'take goods back to a shop' was returning the goods costumer had already purchased to the shop, so the proper word to express that condition was mengembalikan. Translator must know the context of situation when doing a translation job and find the appropriate words or its equivalent to create a natural translation result. Furthermore, the word kwitansi is not commonly used in transaction as the proof of purchase. Many Indonesians are more familiar with struk belanja or resi. Creating a natural translation result can also be done by using familiar word or the 
word commonly used by the people or certain community. By doing this way the readers will also understand the message easily.

Table 13. Data 13

\begin{tabular}{|c|c|c|}
\hline Source Language & $\begin{array}{c}\text { Target Language } 1 \text { (TL1) } \\
\text { GT13 }\end{array}$ & $\begin{array}{c}\text { Target Language } 2 \text { (TL2) } \\
\text { NG13 }\end{array}$ \\
\hline $\begin{array}{l}\text { Many shops may refuse } \\
\text { (illegally, if the product you } \\
\text { have bought is faulty or } \\
\text { defective) to give a refund, } \\
\text { and instead of returning your } \\
\text { money will offer you a credit } \\
\text { voucher to use in that shop at a } \\
\text { later date. }\end{array}$ & $\begin{array}{l}\text { Banyak toko yang mungkin } \\
\text { menolak (secara ilegal, jika } \\
\text { produk yang Anda beli salah } \\
\text { atau cacat) } \\
\text { mengembalikan uang, dan } \\
\text { alih-alih mengembalikan uang } \\
\text { Anda akan menawarkan } \\
\text { voucher kredit untuk } \\
\text { digunakan di toko itu di } \\
\text { kemudian hari. }\end{array}$ & $\begin{array}{l}\text { Banyak toko yang mungkin } \\
\text { menolak (jika produk yang } \\
\text { Anda beli salah atau cacat) } \\
\text { untuk mengembalikan uang } \\
\text { yang telah Anda bayarkan } \\
\text { dan alih-alih mengembalikan } \\
\text { uang Anda, pihak toko akan } \\
\text { menawarkan kupon untuk } \\
\text { digunakan di toko itu di } \\
\text { kemudian hari. }\end{array}$ \\
\hline
\end{tabular}

In data 13 above the problem was on the word 'illegally'. This word refers to many things depending on the context and it sometimes has negative connotation. When Google Translate translated it literally in TL1, then the meaning became unclear, what the word illegally referred to. Was it illegal to purchase defective goods? Or was it illegal to return the customers' money because of the defective goods they purchase? Then in TL2 the word 'illegally' was eliminated in fact it did not change the meaning. The important thing in translation's goal is maintaining the meaning even though the structure or the form of the sentence changes.

Table 14. Data 14

\begin{tabular}{llll}
\hline \multicolumn{1}{c}{ Source Language } & \multicolumn{2}{c}{ Target Language 1 (TL1) } & \multicolumn{2}{c}{ Target Language 2 (TL2) } \\
NT14 & \multicolumn{1}{c}{ NG14 } \\
\hline Where goods and services are & Ketika barang dan jasa dipesan & Ketika barang dan jasa \\
ordered on the internet, on-line & di internet, toko-toko on-line & dipesan melalui internet, \\
shops should offer their & harus menawarkan pelanggan & toko-toko on-line harus \\
customer a cooling-off period & mereka periode pendinginan & memberi waktu jeda kepada \\
after they have ordered them, & setelah mereka memesan, jika pembeli jika mereka tiba-tiba \\
in case the customer decides to & pelanggan memutuskan untuk ingin membatalkan \\
suddenly cancel their order. & $\begin{array}{l}\text { tiba-tiba membatalkan pesanan } \\
\text { mereka. }\end{array}$ & pesanannya. & \\
\hline
\end{tabular}

Data 14 was interesting because of the use special term such as 'cooling-off period'. This term is commonly used in insurance policy or things related to transaction. As it is mentioned in Oxford Dictionary [9], the term means an interval after a sales contract is agreed upon during which the purchaser can decide to cancel without loss. As a result, the translation result in TL1 did not fit with the context because it was translated literally to pendinginan. So, the term was translated to waktu jeda. It was the time given to the customer to decide whether or not he or she wanted to purchase the product and made the payment. 'Cooling-off period' was given to customer to anticipate if the customers change their mind and they want to cancel the purchase. 
Table 15. Data 15

\begin{tabular}{|c|c|c|}
\hline Source Language & $\begin{array}{c}\text { Target Language } \\
\text { GT15 }\end{array}$ & $\begin{array}{c}\text { Target Language } \\
\text { NG15 }\end{array}$ \\
\hline $\begin{array}{l}\text { On-line shops should give the } \\
\text { customer an accurate } \\
\text { description of the goods being } \\
\text { sold, and clearly state the price, } \\
\text { delivery arrangement and } \\
\text { option (how and when the } \\
\text { customer can expect to receive } \\
\text { their goods, whether there is an } \\
\text { extra charge for postage, etc). }\end{array}$ & $\begin{array}{lr}\text { Toko on-line harus memberi } \\
\text { pelanggan deskripsi } \\
\text { akurat tentang barang yang } \\
\text { dijual, dan dengan jelas } \\
\text { menyatakan harga, pengaturan } \\
\text { pengiriman dan opsi } \\
\text { (bagaimana dan kapan } \\
\text { pelanggan dapat mengharapkan } \\
\text { untuk menerima barang-barang } \\
\text { mereka, apakah ada biaya } \\
\text { tambahan untuk ongkos kirim, } \\
\text { dll). }\end{array}$ & $\begin{array}{l}\text { Toko on-line harus memberi } \\
\text { deskripsi produk yang jelas } \\
\text { beserta harganya dan } \\
\text { pengaturan pengiriman } \\
\text { kepada pelanggan, juga } \\
\text { pengaturan lainnya } \\
\text { (bagaimana dan perkiraan } \\
\text { waktu kapan pelanggan } \\
\text { menerima barang-barang } \\
\text { mereka, apakah ada biaya } \\
\text { tambahan ongkos kirim, dan } \\
\text { lain-lain). }\end{array}$ \\
\hline
\end{tabular}

Data 15 showed a literal translation done by Google Translate [TL1], especially the phrase dengan jelas menyatakan harga. By translating word by word, the translation result became unnatural and ineffective. The appropriate translation result was shown in TL2, it could be written Toko on-line harus memberi deskripsi produk yang jelas beserta harganya. The sentence was more effective and concise. The word opsi was also changed into pengaturan lainnya because it still related to arrangement option on how and when the goods will be received.

\section{Conclusions}

In translation to use or not to use the translation tools such as Google Translate is a matter of choice. The translation process is an intellectual activity which needs a thorough thinking. It is not merely about transforming the source language to receptor or target language, but many factors should be considered in order to produce high quality translation product such as diction, context, nuance, culture. According to the findings and discussion above there were some translation results which was actually acceptable, to be understood by the reader, on the contrary some of the results still needs revision. Furthermore, the revision should be made as a consequence of the drawbacks Google Translate have such as: first, ineffective sentence, the sentences used are not straight forward. Second, word per word translation, mostly the context is being ignored; third, the special term cannot be translated correctly; fourth, it only works well on translating simple sentence.

Despite all of the drawbacks, Google Translate does have positive things, such as cheap because it costs nothing in other word it is free, instant because it translated text quickly, and accessible because it can be done simply through a phone mobile.

\section{References}

[1] M. Susanto, “Apa itu Revolusi Industri,” Zenius, 2019. [Online]. Available: www.zenius.net/blog.

[2] F. Maulidiyah, "To use or not to use Google Translate in English language learning," $J$. Linguist. Terap., vol. 8, no. 2, pp. 1-6, 2018. 
[3] X. Chen, S. Acosta, and A. E. Barry, "Evaluating the accuracy of Google translate for diabetes education material," JMIR diabetes, vol. 1, no. 1, p. e5848, 2016.

[4] M. L. Larson, Meaning-based translation: A guide to cross-language equivalence. University press of America, 1984.

[5] L. D. Adisetia, "A Translation Analysis of Idiomatic Expressions in Chocolat by Joanne Harris and Its Translation by Ibnu Setiawan," Univ. Yogyakarta Unpubl. Pap., 2013.

[6] J. Creswell, Research Design: Pendekatan Kualitatif, Kuantitatif, dan MIxed. 2013.

[7] C. Erlingsson and P. Brysiewicz, "A hands-on guide to doing content analysis," African J. Emerg. Med., vol. 7, no. 3, pp. 93-99, 2017.

[8] C. Ptacek, "Using morphological content analysis to mine insights from qualitative interviews," Quirk's Mark. Res. Rev., vol. 23, no. 3, pp. 34-39, 2009.

[9] Oxford English, Oxford English Dictionary. Digital Publisher, 1976. 